УДК: 351.851+351.854:316.42/43(477)

DOI: 10.26697/ijes.2019.4.16

\section{Освіта і наука у системі соціального розвитку України}

Професор Поліщук В. М. ${ }^{\mathbf{1}}$

${ }^{1}$ Київський університет імені Бориса Грінченка, Украӥна

\section{Резюме}

\section{Вступ:}

Будь-яка актуальна проблематика освіти і науки це "вічна декларативна проблематика", якщо іiі розв'язання базується навіть на результативному, але все ж тимчасовому усуненні різнопланових наслідків. Однак саме першопричини проблем, де провідними $\epsilon, \quad$ наприклад, “невідповідність фінансової винагороди фізичним та інтелектуальним затратам науково-педагогічних працівників”, “знецінення соціального статусу вченого", зрештою - "суспільна дискредитація феномена “вищої освіти”, який завжди асоціювався у громадян з найвищим ранговим інтелектуальним показником його суб'єктів, пояснюють сучасний кризовий стан освіти і науки в Україні, який, відображаючи задавнені, з 1990-х рр., несприятливі соціально-економічні трансформації, вже давно сягнув “апогею”.

\section{Методи:}

Предметом нашого лонгітюдного дослідження разом 3 поперечними зрізами $€$ закономірності розвитку сучасної української освіти і науки. Базові методи дослідження: 1) теоретичні (системноструктурний аналіз, історико-логічний аналіз); 2) емпіричні (анкетування, аналіз продуктів діяльності, спостереження, біографічний метод, контент-аналіз, нестандартизовані самозвіти, моделювання), 4) математичні: кореляційний аналіз, рангування даних.

\section{Результати:}

У хронології 1990-2019 рр. виокремлено умовні етапи розвитку освіти і науки України, позначених прогресуючою девальвацією феномена “вищої школи” (як приклад, для кожного етапу наводиться одна із системних характеристик): 1) етап романтичних сподівань (1991-1994 pp.): “прагнення створити якісний вітчизняний освітній простір на основі власних творчих здобутків у поєднанні із західноєвропейськими освітніми досягненнями" - i, водночас, “абсолютизація стагнаційних процесів у системі освіти СРСР, скептицизм в оцінці вітчизняного освітнього i наукового потенціалу разом з абсолютизацією вже західноєвропейської університетської освіти"; 2) пошук власної державницької освітньої моделі (1994-2001 рр.): "масове створення університетських установ під егідою забезпечення реального доступу громадян до здобуття якісної вищої освіти" - “тотальна комерціалізація навчання i, як, наслідок, тенденційне зниження професійних вимог до студентів у ситуації їх полярної готовності до вишівського навчання (передусім інтелектуальної)"; 3) етап початкової системної інтеграції у західноєвропейський освітній простір (2001-2005 рр.): “приєднання України (2005 р.) до Болонської декларації (1999р.) про стандартизацію підходів в організації навчання і функціонування вищої школи в СC” - “стрімке зростання навчальної “бухгалтеріі” в оцінці успішності студентів, що започаткувало першу "паперову хвилю” в навчально-методичній документації викладачів, відволікаючи їх від реальної розвивальної суб'єктної взаємодії”; 4) етап самостійного впровадження закладами вищої освіти КМСОНП, або кредитно-модульної системи організації навчального процесу (2005-2010рр.): “розроблення теоретико-методологічних основ КМСОНП, або набуття неформальної навчальної автономії" - "відносна збалансованість управлінських взаємин 3 центральними освітніми інстанціями"; 5) централізація вищої освіти (20102014 рр.): “стрімке накопичення декларативної навчально-методичної документації” “трансформація викладача як творчої особистості у чиновника"; 6) етап проголошення децентралізації вищої освіти (2014-..): “стабілізація тенденційного зниження у суб'єктів “вищої школи” професійної або навчально-професійної мотивації”.

\section{Висновки:}

1. Проблеми освіти і науки - це державні проблеми, а не проблеми лише окремих закладів вищої освіти. Як наслідок, стабілізація несприятливих першопричин таких проблем $\epsilon$ обов'язковим дороговказом безперспективного розвитку освіти i науки в цілому (втрата ініціативності, розроблення малодоказових технологій тощо), зрештою занепаду, а, значить, прогресування соціальноекономічних, воєнних загроз тощо для безпеки держави.

2. Основним суб'єктом у стратегічному розв'язанні проблем освіти i науки $€$ науково-педагогічний працівник як вчений, але в умовах сучасних соціальних викликів для професійного саморозвитку (відсутність доказового посадового диференційованого навчального перевантаження, розроблення декларативної документації тощо) він реально чи потенційно неспроможний інтенсивно продукувати якісні навчально-наукові результати.

\section{Інформація про автора:}

Поліщук Валерій Миколайович - доктор психологічних наук, професор, Заслужений працівник освіти України, професор кафедри психології та соціальних практик, Київський університет імені Бориса Грінченка, Київ, Україна. Наукові інтереси: методологія досліджень, соціальна психологія, психологія розвитку, історія психологія, інженерна психологія; http://orcid.org/0000-0002-1283-1640.

\section{Автор-Кореспондент:}

Поліщук Валерій Миколайович

Email Автора-Кореспондента:

swetlana.a.polischuck@gmail.com 